\title{
Protection of Human Right for Pregnant Women in Implementing HIV/AIDS Screening for Prevention of HIV/AIDS transmission from mother to Child in Bantul District Health Center
}

\author{
(Perlindungan Hak Asasi Manusia Bagi Ibu Hamil dalam Pelaksanaan Skrining HIV/AIDS untuk \\ Pencegahan Penularan HIV/AIDS dari Ibu ke Anak di Puskesmas Kabupaten Bantul) \\ Tyan Ferdiana Hikmah, Agnes Widanti, I Edward Kurnia SL \\ email: tyanfh94@gmail.com \\ Health Law Master Program, Soegijapranata Catholic University of Semarang
}

\begin{abstract}
HIV / AIDS is a health problem in the world which is constantly increasing, especially in women during pregnancy. The government has made efforts to prevent the spread of HIV / AIDS from mother to child where one of its components is to screen for pregnant women. Implementation of HIV / AIDS screening at Puskesmas Bantul District still focuses on increasing coverage of visit in Puskesmas, not yet paying attention to how the protection of human rights for pregnant women.

The research method was sociological juridical, with the descriptive-analytical specification. Primary data were obtained from interviews with four midwives, four persons in charge of the program, four heads of community health centres and four heads of the health centre and one person in Health Office's Bantul District and eight pregnant women as well as observation at four health centres in Bantul district. Secondary data were legal materials, official documents, books and research journals. Data analysis using qualitative was inductive.

Implementation of HIV / AIDS screening for pregnant women is regulated in Minister of Health Regulation Number 97, 2017 and Minister of Health Regulation Number 51, 2013 about prevention of mother to child transmission of HIV /AIDS-related to the protection of human rights for pregnant women. The protection of human rights for pregnant women in the implementation of HIV / AIDS screening at the Bantul District Health Center has not been fulfilled in terms the rights of information, the rights of consent, and the rights of confidentiality. Supporting factors include the availability of health facilities, supporting health resources, supporting facilities and infrastructures while inhibiting factors are health services, a limited number of counsellors, social support (husbands, health workers, community leaders), affordability, pregnant women working, knowledge, social factors, and the implementation of legislation.
\end{abstract}

Keywords: Health services, maternal human rights, HIV/ AIDS screening, pregnant women 
SOEPRA Jurnal Hukum Kesehatan

ISSN:2548-818X (media online) Vol. 5 | No. 1| Juni 2019

\section{PENDAHULUAN}

Hak Asasi Manusia (HAM) merupakan anugerah Tuhan Yang Maha Esa yang wajib untuk dihormati, dijunjung tinggi, dan dilindungi oleh negara, hukum, pemerintah, dan setiap orang demi kehormatan serta perlindungan harkat dan martabat manusia, termasuk pada seorang perempuan. Setiap ibu hamil mempunyai hak-hak khusus yang berkaitan dengan HAM yang diakui dan dilindungi oleh Undang-Undang, antara lain di bidang kesehatan yang dilaksanakan pada saat melakukan pemeriksaan kehamilan, dimana dalam pemeriksaan kehamilan tersebut terdapat pemeriksaan diagnostik yaitu skrining Human Immunodeficiency Virus (HIV)/ Acquired Immune Deficiency Syndrome (AIDS) yang selanjutnya disingkat HIV/AIDS yang telah dilakukan selama ini sebagai bagian dari layanan kesehatan ibu dan anak yaitu pada saat pemeriksaan Antenatal Care.

Dinas Kesehatan Kabupaten Bantul melaporkan jumlah ibu hamil secara keseluruhan pada tahun 2016 tercatat 13.250 ibu hamil sedangkan jumlah ibu hamil positif sebanyak 18 orang, yang terdiri dari 6 orang yang datang dengan HIV dan 12 orang ibu hamil dari skrining HIV/AIDS sewaktu hamil, Kabupaten Bantul terdapat 17 Kecamatan, dimana urutan kasus HIV/AIDS paling banyak ditemukan di empat Kecamatan yaitu Kretek, Kasihan, Srandakan, dan Imogiri.

Pasal 17 Peraturan Daerah Provinsi Daerah Istimewa Yogyakarta No. 12 Tahun 2010 Tentang Penanggulangan Human Immunodefficiency Virus (Hiv) dan Acquired Immuno Defficiency Sindrome (AIDS) menjelaskan bahwa skrining HIV/AIDS wajib didahului dan diakhiri konseling atau pemberian informasi, dalam hal ini jika pasien menyetujui untuk melakukan skrining HIV harus memberikan persetujuan tertulis setelah memperoleh penjelasan yang memadai tentang HIV dan AIDS, serta pasien berhak menolak dilakukannya skrining HIV/AIDS dengan tetap memperhatikan aspek kerahasiaan didalamnya.

Aspek yang menjadi fokus utama saat ini adalah masih berpacu dengan bagaimana cara meningkatkan cakupan tes pada pelaksanaan skrining HIV/AIDS yang ada, bukan sebagai salah satu jalan cara untuk memastikan bahwa ibu hamil akan mendapatkan pemenuhan hak asasinya dalam pelayanan kesehatan untuk tetap terhubung dengan layanan lanjutan sejak dini. Permasalahan pada pelaksanaan skrining HIV/AIDS bagi ibu hamil adalah diantaranya pertama dikaji dari aspek pemberian konseling yang relatif singkat, mengingat diberikan sebagai bagian dari Antenatal Care (ANC) terpadu, maka ada kecenderungan bahwa konseling hanyalah sebatas pemberian informasi.

Masalah kedua yaitu berkaitan dari segi persetujuan (informed consent), pedoman World Health Organization (WHO) maupun Kemenkes menekankan bahwa ibu hamil berhak untuk menolak tawaran untuk skrining HIV/AIDS. Masalah yang ketiga yaitu terkait dengan aspek konfidensilitas (kerahasiaan) yang seharusnya pada pelaksanaannya penulisan hasil pemeriksaan dalam rekam medik pasien serta buku Kesehatan Ibu dan Anak (KIA) dengan kode Non Reaktif (NR) dan Reaktif ( R ).

Sesuai dengan metode pendekatan pencegahan penularan HIV/AIDS tahun 2012, pelayanan kesehatan ibu dan anak yang komprehensif mencakup kegiatan salah satunya layanan ANC terpadu termasuk penawaran dan skrining HIV/AIDS, tetapi pada pelaksanaannya ibu hamil kurang mendapatkan The Right of Self Determination yang disebut hak dasar atau hak primer 
SOEPRA Jurnal Hukum Kesehatan

ISSN:2548-818X (media online) Vol. 5 | No. 1 | Juni 2019

individual yang merupakan sumber dari hak-hak individual yaitu bisa diimplementasikan hak atas kerahasiaan serta hak atas tubuhnya sendiri yaitu dengan informed consent. Selain itu, The Right to Health Care atau hak atas pelayanan kesehatan yang diimplementasikan dalam hak utuk memperleh konseling yang relevan baik pra-test maupun post-test. Hal itulah yang mendasari peneliti tertarik untuk menganalisis "PERLINDUNGAN HAK ASASI MANUSIA (HAM) BAGI IBU HAMIL DALAM PELAKSANAAN SKRINING HIV/AIDS UNTUK PENCEGAHAN PENULARAN HIV/AIDS DARI IBU KE ANAK DI PUSKESMAS KABUPATEN BANTUL".

\section{PERUMUSAN MASALAH}

1. Bagaimanakah pengaturan pelaksanaan skrining HIV/AIDS bagi ibu hamil di Puskesmas Kabupaten Bantul?

2. Bagaimanakah perlindungan HAM bagi ibu hamil dalam pelaksanaan skrining HIV/AIDS di Puskesmas Kabupaten Bantul?

3. Bagaimanakah faktor pendukung dan faktor penghambat pelaksanaan skrining HIV/AIDS bagi ibu hamil di Puskesmas Kabupaten Bantul?

\section{METODE PENELITIAN}

\section{Metode Pendekatan}

Penelitian ini menggunakan metode pendekatan yuridis sosiologis, Faktor yuridis dalam penelitian ini adalah semua peraturan yang berkaitan dengan perlindungan Hak Asasi Manusia (HAM) bagi ibu hamil, sedangkan faktor sosiologisnya adalah pelaksanaan skrining HIV/AIDS untuk pencegahan penularan HIV/AIDS dari ibu ke anak di Puskesmas Kabupaten Bantul.

\section{Spesifikasi Penelitian}

Penelitian ini menggunakan spesifikasi penelitian yaitu deskriptif analitik.

\section{Subjek dan Objek Penelitian}

a. Penelitian ini menggunakan subjek penelitian Ibu hamil, Bidan, Dokter, Kepala Puskesmas, dan Dinas Kesehatan Kabupaten Bantul.

b. Objek dalam penelitian ini adalah perlindungan Hak Asasi Manusia (HAM) bagi ibu hamil dalam pelaksanaan skrining HIV/AIDS. Elemen penelitian meliputi hak dalam memperoleh informasi melalui konseling, persetujuan dan kerahasiaan bagi ibu hamil dalam pelaksanaan skrining HIV/AIDS untuk pencegahan penularan HIV/AIDS dari ibu ke anak di Puskesmas Kabupaten Bantul.

\section{Jenis data}

Jenis data dalam penelitian adalah data primer dan dikuatkan dengan data sekunder. Data primer diperoleh melalui wawancara mendalam dan observasi. Data sekunder yang digunakan dalam penelitian yang dilakukan ini terdiri dari berbagai bahan hukum, yaitu: 
a) Bahan hukum primer yaitu bahan-bahan hukum yang mengikat dalam usulan penelitian ini meliputi UUD 1945, UU, Pergub dan Permenkes.

b) Bahan hukum sekunder

Bahan hukum sekunder yang digunakan dalam penelitian ini antara lain:

1) Kepustakaan yang berkaitan dengan penelitian ini adalah buku tentang metodologi penelitian hukum kesehatan, Hak Asasi Manusia (HAM), pedoman perlindungan hak asasi perempuan, pedoman pelaksanaan skrining HIV/AIDS dan pedoman pelayanan kesehatan di Puskesmas.

2) Hasil ilmiah yang berkaitan dengan materi penelitian, berupa jurnal ilmiah, tentang perlindungan hak asasi manusia bagi ibu hamil dalam pelaksanaan skrining HIV/AIDS.

c) Bahan hukum tersier

Pada penelitian ini digunakan bahan hukum tersier berupa kamus hukum dan kamus kedokteran.

\section{Metode Pengumpulan Data}

a) Studi Kepustakaan

b) Studi lapangan

Teknik dan/atau cara penentuan responden dalam penelitian ini adalah Non Probability Sampling. Narasumber yang digunakan dalam penelitian ini adalah Penanggung jawab program penanggulangan HIV/AIDS sebanyak 1 orang di masing-masing Puskesmas, Bidan koordinator sebanyak 1 orang di masing-masing Puskesmas sehingga total untuk jumlah narasumber bidan sebanyak 4 orang, Kepala Puskesmas sebanyak 1 orang di masing-masing Puskesmas sehingga total jumlah narasumber Kepala Puskesmas sebanyak 4 orang, Dinas Kesehatan Kabupaten Bantul Bidang Pengendalian Penyakit Menular (P2M) sebanyak 1 orang.

\section{Metode Analisis Data}

Analisis data yang digunakan adalah dengan menggunakan pendekatan kualitatif terhadap data primer dan sekunder. Langkah analisis data yang dilakukan oleh peneliti adalah:

a. Pengumpulan data

b. Penyajian Data 
SOEPRA Jurnal Hukum Kesehatan

ISSN:2548-818X (media online) Vol. 5 | No. 1 | Juni 2019

\section{PEMBAHASAN}

\section{Pengaturan Hukum dalam Skrining HIV/AIDS Bagi Ibu Hamil}

\section{a. Undang-Undang Dasar 1945}

Pelayanan kesehatan bagi ibu hamil maka ibu hamil berhak mendapat perlakuan yang adil dan sesuai dengan nilai-nilai bangsa yang beradab, termuat dalam Pasal 28D ayat (1) UUD 1945. Pelaksanaan hak seorang individu tidaklah bebas mutlak, dimana dalam manjalankan haknya maka harus menghormati hak orang lain termuat dalam Pasal $28 \mathrm{H}$ ayat (1).

\section{b. UU No. 39 tahun 1999 tentang Hak Asasi Manusia (HAM)}

Perlakuan khusus termasuk ibu hamil tercantum pada Pasal 41 ayat (2), ibu hamil termasuk kelompok khusus dan perlu mendapatkan kemudahan dan perlakuan khusus karena ibu hamil mengandung anak yang membutuhkan perlindungan secara ganda baik untuk ibu hamil itu sendiri dan anak yang dikandungnya utamanya pada aspek kesehatan, sehingga ibu hamil memerlukan kemudahan dan bantuan orang lain dalam segala tindakannya.

c. UU No. 23 tahun 2004 tentang Praktik Kedokteran

Masalah AIDS banyak sangkut pautnya dengan dengan rahasia kedokteran berikut tercantum dalam Pasal 48 ayat (1). Hak pasien dalam hal ini adalah ibu hamil pada saat menerima pelayanan kesehatan termuat dalam Pasal 52 ibu hamil ini memiliki hak diantaranya adalah menolak tindakan medis.

d. Peraturan Menteri Kesehatan No. 290/MENKES/PER/III/2008 tentang Persetujuan Tindakan Kedokteran

Pasal 3 menyebutkan bahwa pelaksanaan skrining HIV/AIDS pada kenyataannya tidak mengandung banyak risiko seperti tindakan invasif, tetapi karena persetujuan ini merupakan salah satu bentuk kebebasan seseorang dalam menentukan sendiri terkait dengan kesehatannya. Penolakan tindakan kedokteran tercantum dalam Pasal 16.

e. UU No. 36 tahun 2009 tentang Kesehatan

Undang-Undang Nomor 36 Tahun 2009 tentang Kesehatan (UU Kesehatan) sudah mencantumkan standar hak asasi manusia secara internasional, karena terdapat dalam hal ini membutuhkan adanya asas keseimbangan, perlindungan dan penghormatan terhadap hak dan kewajibannya, serta non diskriminasi didalam segala aspeknya. Pasal 4 dinyatakan bahwa setiap orang berhak atas kesehatan sehingga semua orang berhak untuk menjaga kesehatannya, yaitu salah satunya dengan skrining HIV/AIDS bagi ibu hamil.

f. Permenkes $\mathbf{5 1}$ tahun 2013 tentang Pedoman Pencegahan Penularan HIV dari lbu ke Anak Analisis struktural mengarahkan kepada pandangan para tenaga kesehatan untuk tuntutan strategis (jangka panjang) yang menjadi dasar upaya penanggulangan HIV/AIDS yang efektif dan berkesinambungan. Pandangan baru mengenai cara pencegahan dan penanggulangan HIV/AIDS sudah seharusnya diketahui dengan cara memberdayakan 
SOEPRA Jurnal Hukum Kesehatan

ISSN:2548-818X (media online) Vol. 5 | No. 1| Juni 2019

perempuan pada umumnya dengan cara menyentuh aspek keadilan menggunakan perspektif hak asasi perempuan (woman's human rights).

g. Peraturan Menteri Kesehatan Republik Indonesia Nomor 97 Tahun 2014 Tentang Pelayanan Kesehatan Masa Sebelum Hamil, Masa Hamil, Persalinan, dan Masa Sesudah Melahirkan, Penyelenggaraan Pelayanan Kontrasepsi, Serta Pelayanan Kesehatan Seksual

Pelaksanaan skrining HIV/AIDS bagi ibu hamil yang mengacu pada hak dalam memperoleh informasi melalui konseling, persetujuan serta kerahasiaan Pasal 12 ayat (3) menegaskan pelaksanaan keempat Puskesmas secara umum sudah berjalan sesuai dengan pedoman yang ada untuk melakukan skrining bagi ibu hamil melalui layanan ANC terpadu.

h. Permenkes RI Nomor 1464/ Menkes/ Per/X/2010 Tentang Izin Dan Penyelenggaraan Praktik Bidan

Pelayanan kesehatan ibu dalam pelaksanaan skrining HIV/AIDS sesuai dengan Pasal 10 ayat (1), bahwa keempat Puskesmas sudah menjalankan pelayanan pada masa pra hamil misalnya dengan konseling persiapan baik calon ibu maupun calon ayah dari anak.

i. UU No. 35 Tahun 2014 tentang Perlindungan Anak

Perlindungan anak terkait dengan hak hidup seorang anak sebagai hak asasi manusia harus dijaga dan dihormati oleh siapapun termasuk mereka yang memiliki anak dengan HIV/AIDS positif sehingga memiliki peluang dapat tertular HIV/AIDS, dalam hal ini adalah orang tua, Pemerintah, Pemerintah Daerah, dan lembaga Negara. Hak hidup anak juga berkaitan dengan hak-hak lain yang merupakan bagian dari HAM yaitu dengan hak untuk dibesarkan, hak untuk dirawat serta penghormatan terkait dengan hak untuk melangsungkan kehidupan. ${ }^{1}$

j. UU No. 36 Tahun 2014 tentang Tenaga Kesehatan

Melihat pentingnya perlakuan non diskriminasi dan kesetaraan dalam menerima pelayanan kesehatan oleh tenaga kesehatan, keempat peraturan ini masih belum memadai dalam hak atas kesehatan bagi orang dengan HIV/AIDS, oleh karena itu dapat dikatakan bahwa peraturan-peraturan tersebut masih terdapat celah hukum yang memungkinkan terjadinya stigma dan diskriminasi.

k. Peraturan Menteri Kesehatan RI No. 21 Tahun 2013 tentang penanggulangan HIV dan AIDS

Pelaksanaan pencegahan termuat dalam Pasal 17 ayat (2), pemeriksaan diagnosis HIV/AIDS merupakan salah satu upaya untuk pencegahan sedini mungkin dari penyakit tersebut, kaitannya dengan ibu hamil adalah untuk pencegahan penularan HIV/AIDS dari ibu ke anak dalam kandungan, sehingga dalam hal ini ibu hamil memiliki perlindungan khusus dalam The right of to health care atau hak dalam perlindungan atas kesehatannya. Prinsip konfidensial sebagaimana dimaksud pada Pasal 21 ayat (3).

${ }^{1}$ Novry Oroh, 2013, Perlindungan Hak Hidup Terhadap Anak Yang Baru Dilahirkan, Manado: Program Studi IImu Hukum Pascasarjana Universitas Sam Ratulangi, hal 1. 
I. Peraturan Menteri Kesehatan Nomor 74 Tahun 2014 tentang Pedoman Pelaksanaan Konseling dan Tes HIV

Pasal 4 ayat (1) dan (2), menyebutkan bahwa pelakasanaan skrining HIV/AIDS dilakukan di fasilitas pelayanan kesehatan dalam hal ini adalah di Puskesmas. Pelaksanaan di empat Puskesmas sudah menerapkan hal tersebut. Pasal 7 menjelaskan bahwa pelayanan konseling dan tes HIV harus dilakukan pencatatan dan pelaporan sesuai denga peraturan yang ada sesuai dengan kebijakan bahwa pelaporan dilakukan secara berjenjang setiap 1 (satu) bulan.

m. Permenkes No. 75 tahun 2014 tentang Pusat Kesehatan Masyarakat

Pasal 5 mensyaratkan adanya kewajiban untuk memberikan fasilitas kesehatan bagi semua orang tanpa terkecuali, termasuk bagi orang dengan HIV/AIDS. Elemen hak atas kesehatan yang terkandung dalam regulasi tersebut berfokus pada tersedianya fasilitas pelayanan kesehatan seperti rumah sakit dan puskesmas yang merupakan institusi pelayanan kesehatan yang menyelenggarakan pelayanan kesehatan sehingga ketersediaannya sangat dibutuhkan untuk mencapai derajat kesehatan setinggitingginya.

n. Peraturan Gubernur Daerah Istimewa Yogyakarta Nomor 12 Tahun 2010 Tentang Penanggulangan Human Immunodefficiency Virus (HIV) dan Acquired Immuno Defficiency Sindrome (AIDS)

Asas Penanggulangan HIV dan AIDS termuat dalam Pasal 2 yang meliputi kemanusiaan, keadilan, kesetaraan jender, kebersamaan, terpadu, berkesinambungan, rahasia dan sukarela. Persetujuan pada pelaksanaan skirining HIV/AIDS termuat dalam Pasal 17 ayat (3), sedangkan hak menolak dilakukannya skrining HIV/AIDS termuat dalam Pasal 17 ayat (4). Pasal 17 ayat (5) metode pendekatan yang digunakan oleh Puskesmas dalam pelaksanaan skrining HIV/AIDS adalah Provider Initiated Counselling and Testing (PITC) sehingga pasal di peraturan ini tidak digunakan, tenaga kesehatan berkewajiban untuk menawarkan skrining HIV/AIDS ini.

2. Perlindungan Hak Asasi Manusia Bagi ibu Hamil dalam Pelaksanaan Skrining HIV/AIDS di Puskesmas Kabupaten Bantul

Tabel 3. 5 Hasil Wawancara Responden tentang Perlindungan Hak Asasi Manusia dalam Pelaksanaan Skrining HIV/AIDS

\begin{tabular}{|l|l|l|c|c|c|c|c|c|}
\hline \multirow{2}{*}{$\begin{array}{l}\text { Perlindungan bagi } \\
\text { ibu hamil dalam } \\
\text { pelaksanaan } \\
\text { skrining HIV/AIDS }\end{array}$} & \multicolumn{9}{|c|}{\begin{tabular}{c} 
Responden \\
\cline { 2 - 9 }
\end{tabular}} & Kaskesmas & \multicolumn{2}{c|}{$\begin{array}{c}\text { Puskesmas } \\
\text { Imogiri I }\end{array}$} & \multicolumn{2}{c|}{$\begin{array}{c}\text { Puskesmas } \\
\text { Kretek }\end{array}$} & \multicolumn{2}{c|}{$\begin{array}{c}\text { Puskesmas } \\
\text { Srandakan }\end{array}$} \\
\cline { 2 - 10 } & I & II & I & II & I & II & I I \\
\hline Konseling & Tidak & Tidak & Tidak & Tidak & Tidak & Tidak & Ya & Tidak \\
\hline Persetujuan & Ya & Tidak & Tidak & Tidak & Ya & Tidak & Tidak & Ya \\
\hline Kerahasiaan & Tidak & Tidak & Tidak & Ya & Tidak & Ya & Tidak & Tidak \\
\hline
\end{tabular}


SOEPRA Jurnal Hukum Kesehatan

ISSN:2548-818X (media online) Vol. 5 | No. 1 | Juni 2019

Keterangan : I Responden ibu hamil pertama

II Responden ibu hami kedua

Tabel 3.5 menunjukkan bahwa hasil wawancara terhadap 8 orang ibu hamil didapatkan hasil bahwa perlindungan HAM dalam pelaksanaan skrining HIV/AIDS bagi ibu hamil di Puskesmas Kasihan 2 belum terpenuhi secara keseluruhan, Ibu hamil belum pernah diberi tau sebelumnya jika hasil positif/ negatif setelah dilakukan pemeriksaan, ibu belum mengetahui terkait dengan tanda bahaya dari penyakit HIV/AIDS, ibu belum pernah dijelaskan prosedur pelaksanaan skrining HIV/AIDS. Menurut pengamatan peneliti bahwa, Ibu membutuhkan informasi lebih dalam terkait upaya pencegahan yang harus dilakukan pada penyakit menular termasuk HIV/AIDS, tetapi kebutuhan akan informasi dari ibu hamil tersebut belum bisa dipenuhi sepenuhnya.

Tidak terpenuhinya hak asasi bagi ibu hamil dalam pemberian informasi dan kerahasiaan diantaranya masih banyak seperti jumlah Sumber Daya Manusia (SDM) yang belum mengikuti pelatihan tentang skrining HIV/AIDS bagi ibu hamil, sarana prasarana untuk runag konseling, kode hasil skrining HIV/AIDS dan cara penulisan belum sama antar Puskesmas, tetapi Kepala Puskesmas Kasihan II mengatakan bahwa masih diupayakan untuk terus mengalami peningkatan pelayanan, prinsip dan hak terkait informasi, persetujuan dan kerahasiaan masih diupayakan semaksimal mungkin untuk bisa dipenuhi bagi kebanyakan ibu hamil.

Merujuk tabel 3. 5 didapatkan hasil bahwa perlindungan HAM bagi ibu hamil dalam pelaksanaan skrining HIVAIDS bagi ibu hamil di Puskesmas Imogiri I belum terpenuhi secara keseluruhan. Perlindungaan HAM yang tidak dipenuhi oleh reponden I dan II adalah perlindungaan HAM dalam memperoleh informasi melalui konseling pra test dan konseling post test serta perlindungaan HAM dalam memperoleh persetujuan.

Sesuai dengan Pasal 56 Undang-Undang Kesehatan diatur tentang persetujuan tindakan medis atau informed consent. Skrining HIV harus mendapatkan informed consent dari ibu hamil setelah ibu hamil diberikan informasi yang cukup tentang tes, tujuan tes, implikasi hasil tes positif ataupun negatif yang berupa konseling pra tes. ${ }^{2}$ Hal tersebut dikarenakan bahwa jumlah pasien yang ada di Puskesmas tidak sebanding dengan jumlah tenaga kesehatan yang terlatih di masing-masing Puskesmas.

Merujuk tabel 3.2 didapatkan hasil bahwa perlindungan HAM dalam pelaksanaan skrining HIV/AIDS di Puskesmas Kretek belum terpenuhi secara keseluruhan, sesuai dengan hasil wawancara dengan Ibu hamil Reni mengatakan bahwa belum pernah diberitau sebelumnya terkait dengan pemeriksaan ini, yang diketahui hanya sekali datang kemudian diambil darahnya untuk diperiksa HIV/AIDS dan darah lengkap. Berdasarkan Pedoman Kemenkes 2014 menyebutkan bahwa Informasi prates bagi perempuan yang kemungkinan akan hamil atau dalam kondisi hamil harus minimal meliputi risiko penularan HIV kepada bayi yang dikandungnya kelak, cara yang dapat dilakukan guna mengurangi risiko penularan HIV dari

\footnotetext{
${ }^{2}$ Noviana Nana, 2013, Kesehatan Reproduksi HIV-AIDS, Jakarta: Trans Info Media, hal 88.
} 
ibu ke anaknya, termasuk terapi antiretroviral profilaksis dan konseling tentang makanan bayi, keuntungan melakukan diagnosis HIV secara dini bagi bayi yang dilahirkan. Menurut pengamatan peneliti bahwa konseling post test disampaikan hasilnya, jika hasil negatif maka tidak diberikan penjelasan apapun, tetapi jika positif akan diberikan penjelasan kaitannya terapi, penanganan, rujukan dan support serta diserahkan pada tim penanggulangan HIV/AIDS yang ada di Puskesmas.

Hal tersebut tidak sesuai dengan teori, peraturan-perundangan yang ada terhadap pelaksanaan di tempat penelitian ditemukan adanya kendala seperti kurangnya sarana prasarana seperti ruang konseling yang sesuai, serta anggapan bidan yang masih berorintasi pada jumlah cakupan dan jumlah SDM atau bidan yang sudah mengikuti pelatihan PITC terbatas yaitu (1 Puskesmas 1 orang) sehingga bidan merasa kesulitan dalam memberikan perhatian dan pemenuhan hak asasi manusia (HAM) bagi ibu hamil, tetapi di empat Puskesmas berusaha akan mencoba meningkatkan pelayanan, sehingga harapannya ibu hamil dapat memperoleh perlindungan khusus sesuai dengan UU No. 39 tahun 1999 tentang HAM.

Merujuk tabel 3.2 didapatkan hasil bahwa perlindungan hak HAM bagi ibu hamil dalam pelaksanaan skrining HIV/AIDS di Puskesmas Srandakan berdasarkan hasil wawancara terhadap 8 orang ibu hamil didapatkan hasil bahwa perlindungan HAM yang paling banyak terpenuhi oleh ibu hamil adalah HAM dalam memperoleh persetujuan yaitu 3 orang $(37,5 \%)$, sedangakan HAM yang paling sedikit dipenuhi oleh ibu hamil adalah HAM dalam memperoleh informasi melalui konseling baik pratest maupun post test yaitu 1 orang (12,5\%). Pelaksanaan skrining HIV/AIDS pada empat Puskesmas mengacu pada hak memperoleh informasi melalui konseling pra test dan post test, hak memperoleh persetujuan dan hak dalam kerahasiaan walaupun belum berjalan sepenuhnya.

\section{Faktor Pendukung dan Faktor Penghambat}

Faktor yang mendukung perlindungan hak asasi manusia bagi ibu hamil dalam pelaksanaan skrining HIV/AIDS untuk pencegahan penularan HIV/AIDS dari ibu ke anak sebagai berikut:

\section{Ketersediaan fasilitas kesehatan}

Tersedianya fasilitas guna mensukseskan kebijakan yang ada merupakan salah satu faktor pedukung dari pelaksanaan skrining HIV/AIDS, hal ini sesuai dengan Pasal 34 UUD 1945. Fasilitas pelayanan kesehatan yang ada di Kabupaten Bantul secara umum sudah baik, karena ada Puskesmas di setiap Kecamatan serta ada Puskesmas Pembantu hampir di setiap wilayah kerja Puskesmas, sehingga dengan adanya fasilitas kesehatan ini akan menjadi suatu kemudahan bagi masyarakat untuk mengakses kesehatannya, mengingat Puskesmas bertanggung jawab dalam upaya kesehatan masyarakat serta perorangan yang meliputi upaya promotif, preventif, kuratif dan rehabilitatif.

\section{Ketersediaan sumber daya kesehatan pendukung}

Hal tersebut sesuai dengan pasal 1 ayat (2) Undang Undang No. 36 tahun 2009 tentang Kesehatan. Tersedianya Puskesmas pembantu juga akan memudahkan masyarakat dalam mengakses pelayanan kesehatan, serta apabila ditemukan ibu hamil belum dilakukan skrining HIV/AIDS maka bisa di anjurkan untuk melakukan di Puskesmas dan apabila tidak 
dapat ditangani Puskesmas maka akan dilakukan upaya kolaborasi serta rujukan di RSUD. Selain itu, tersedianya reagen untuk rapid test dari HIV/AIDS itu sendiri akan sangat mendukung dari berjalannya skrining HIV/AIDS bagi ibu hamil.

\section{Sarana dan prasarana penunjang}

Sarana dan prasarana penunjang dalam pelaksanaan skrining HIV/AIDS baik didalam ataupun di luar ruangan yaitu diantaranya ruangan konseling yang memadai akan mempengaruhi keberhasilan dari pelaksanaan konseling, ketika ruangan nyaman dengan adanya ruang khusus konseling maka aspek pemberian informasi baik pra test, post test dapat berjalan dengan baik serta aspek hak dalam memproleh kerahasiaan juga akan terpenuhi oleh kebanyakan ibu hamil, sehingga hak memberikan rasa aman dan nyaman bagi ibu hamil bisa tetap terealisasi secara optimal.

Faktor penghambat dalam hal ini adalah:

\section{Faktor Pelayanan Kesehatan}

Faktor pelayanan kesehatan yang merupakan faktor penghambat yang berkaitan dengan keterampilan pemberi pelayanan, antara lain belum ditetapkannya prosedur tetap dalam pelaksanaan skrining HIV/AIDS bagi ibu hamil secara konsisten, tenaga kesehatan masih berpacu pada peningkatan cakupan yang ada belum memperhatikan untuk aspek perlindungan hak asasi manusia yang ada di dalam pelayanan skrining HIV/AIDS, Sistem pelaporan belum diperjelas bagaimana modelnya untuk pelayanan terintegrasi, dan belum ada tenaga khusus untuk pencatatan dan pelaporan, belum adanya komunikasi satu pintu terkait pendokumentasian pelaksanaan skrining HIV/AIDS, dari bidan, dan surveilan yang ada di Puskesmas.

\section{Jumlah tenaga kesehatan (konselor) yang masih terbatas}

Belum banyaknya tenaga kesehatan khususnya bidan yang mengikuti pelatihan terkait dengan skrining HIV/AIDS dengan pendekatan PITC, melihat hal tersebut Pemerintah perlu menambah Sumber Daya Manusia (SDM) yang ada serta peningkatan ketrampilan melalui pelatihan.

\section{Dukungan sosial yang masih rendah}

a) Dukungan suami berupa dukungan dukungan emosi, dukungan informasi, dukungan instrumental dan dukungan penilaian misalnya dengan keikutserataan suami dalam upaya perawatan kehamilan dengan mengantarkan ibu ke Puskesmas.

b) Dukungan tenaga kesehatan berupa dukungan yang diberikan oleh tenaga untuk memenuhi kebutuhannya dalam bidang kesehatan khususnya dalam upaya promosi melalui penyuluhan kesehatan

c) Dukungan yang diberikan oleh kader kesehatan dengan ikut serta mempromosikan serta menginformasikan akan bahaya dan dampak dari HIV/AIDS selama masa kehamilan, penyedian fasilitas dan sarana prasarana untuk penyuluhan serta pertemuan ibu hamil dan kader kesehatan. 


\section{Keterjangkauan rumah dengan Puskesmas}

Jarak rumah yang tergolong jauh dengan Puskesmas menjadi pengaruh yang besar dalam keikutsertaan ibu hamil untuk melakukan skrining HIV/AIDS selama masa kehamilannya. Hal tersebut dikarenakan dengan jarak rumah yang jauh menyebabkan ibu hamil tersebut akan mempengaruhi aksesibilitas masyarakat terhadap pelaksanaan untuk melakukan skrining HIV/AIDS. Jarak pelayanan kesehatan dengan rumah berpengaruh terhadap perilaku ibu hamil untuk melakukan skrining HIV/AIDS, selain itu sebagian kecil dari responden, karena sebagian ibu hamil belum mengetahui pentingnya mengenai pemeriksaan skrining HIV/AIDS.

\section{Ibu hamil yang bekerja}

Ibu hamil yang memiliki status pekerjaan cenderung untuk jarang melakukan pemeriksaan selama kehamilan di Puskesmas, hal ini dikarenakan jam kerja pelayanan Puskesmas yang sama dengan jam kerja yang dimiliki oleh ibu hamil menyebabkan ibu hamil memilih melakukan pemeriksaan kehamilan tidak di Puskesmas, hal inilah yang menyebabkan salah satu faktor dari cakupan di Puskesmas tergolong masih rendah.

\section{Pengetahuan ibu hamil}

Pengetahuan yang tergolong masih rendah mengenai pengertian dan kemanfaatan skrining penyakit menular selama kehamilan termasuk HIV/AIDS yang mengakibatkan ibu hamil tidak melakukan pemeriksaan di Puskesmas. Hal tersebut dapat peneliti lihat dari cakupan ibu hamil yang melakukan pemeriksaan dibandingkan dengan jumlah ibu hamil yang berada di wilayah kerja Puskesmas masih tergolong sedikit, tentang pengertian skinning HIV/AIDS mereka masih belum mengetahuinya.

\section{Faktor Sosial}

Presepsi masyarakat dan budaya bahwa periksa di Puskesmas antrian yang cukup banyak, fasilitas dan sarana prasarana kurang lengkap dan memadai, pelayanan yang kurang optimal menyebabkan masyarakat enggan melakukan pemeriksaan kesehatan di Puskesmas dan memilih untuk melakukan pemeriksaan di fasilitas kesehatan swasta, selain itu keterjangkauan tempat tinggal dengan Puskesmas yang membutuhkan waktu lama sehingga masyarakat memilih untuk melakukan pemeriksaan yang lebih dekat, selain itu transportasi menuju ke Puskesmas tidak banyak seperti halnya di kota-kota besar.

\section{Pelaksanaan Perundang-Undangan khususnya pada pelayanan pada masa kehamilan} belum optimal

Hal tersebut ditunjang dengan belum banyaknya peraturan terkait pelaksanaan skring HIV/AIDS bagi ibu hamil khususnya, mengingat hal ini adalah sesuatu yang sifatnya ditawarkan secara wajib oleh semua ibu hamil dalam mengakses layanan kesehatan di Puskesmas, masih banyak kendala utama bidan dalam melakukan promosi kesehatan kepada ibu hamil karena banyaknya fasilitas kesehatan swasta yang ada. 
SOEPRA Jurnal Hukum Kesehatan

ISSN:2548-818X (media online) Vol. 5 | No. 1 | Juni 2019

\section{KESIMPULAN}

a. Pengaturan perlindungan Hak Asasi Manusia (HAM) bagi ibu hamil dalam pelaksanaan skrining HIV/AIDS untuk pencegahan penularan HIV/AIDS dari ibu ke anak di Puskesmas Kabupaten Bantul, terdapat dalam beberapa Peraturan-Peraturan yang meliputi UUD 1945, UU, Pergub dan Permenkes.

b. Perlindungan HAM bagi ibu hamil dalam pelaksanaan skrining HIV/AIDS di Puskesmas Kabupaten Bantul masih berfokus pada bagaimana cara peningkatan cakupan yang ada, belum memperhatikan bagaimana perlindungan hak asasi ibu hamil tersebut dalam pelaksanaan skrining HIV/AIDS untuk pencegahan penularan HIV/AIDS dari ibu ke anak. Perlindungan hak secara umum belum terpenuhi seluruhnya.

c. Faktor pendukung dalam pelaksanaan skrining HIV/AIDS bagi ibu hamil di Puskesmas Kabupaten Bantul adalah ketersediaan fasilitas kesehatan, ketersediaan sumber daya kesehatan pendukung, sarana dan prasarana penunjang. Faktor penghambat yaitu faktor pelayanan kesehatan kurangnya tenaga kesehatan yang mengikuti pelatihan sebagai konselor di tiap Puskesmas, kurangnya dukungan sosial, jarak rumah ibu hamil dengan Puskesmas yang tergolong jauh, ibu hamil yang bekerja, pengetahuan yang rendah, faktor sosial serta pelaksanaan perundang-undangan.

\section{SARAN}

\section{a. Bagi Tenaga Kesehatan Terkait}

Meningkatkan kesadaran dan menanamkan niat kepada para tenaga kesehatan, mengembangkan dan meningkatkan ilmu pengetahuan serta kemampuan dengan mengikuti pelatihan tes dan konseling pelaksanaan skrining HIV/AIDS, dibutuhkan komunikasi satu pintu terkait pendokumentasian pelaksanaan skrining HIV/AIDS, dari bidan, dan surveilans, pendekatan tokoh masyarakat seperti kader kesehatan yang terlibat dalam pelaksanaan ini serta menjalin kerjasama lintas sektoral dan program guna keberlangsungan dan kesuksesan program.

\section{b. Bagi Dinas Kesehatan Kabupaten Bantul}

Peningkatan ketrampilan petugas kesehatan dengan pelatihan tenaga kesehatan dan konselor, pemenuhan sumber daya manusia yang terampil, dibuatnya kebijakan pendukung tentang pentingnya memberikan dan memperhatikan perlindungan hak asasi bagi ibu hamil, menambah penyebaran bidan di Puskesmas, memberdayakan kader kesehatan di wilayah kerja Puskesmas untuk mendukung kebijakan, peningkatan monitoring dan evaluasi dari Dinas Kesehatan terkait dengan pelaksanaan skrining HIV/AIDS bagi ibu hamil, sistem pelaporan harap diperjelas bagaimana modelnya untuk pelayanan terintegrasi, menambah tenaga khusus untuk pencatatan dan pelaporan.

\section{c. Puskesmas yang Terlibat dalam Penelitian}

Peningkatan softskills, sarana prasarana, pencatatan dan pelaporan perlu diperbaiki dengan melakukan apresepsi terkait penulisan hasil tes di buku KIA, harapannya hak terkait informasi dapat dipenuhi oleh ibu hamil, menetapkan Standar Operasional Prosedur (SOP) 
SOEPRA Jurnal Hukum Kesehatan

ISSN:2548-818X (media online) Vol. 5 | No. 1 | Juni 2019

secara terintegrasi antar Puskesmas, adanya layanan untuk mempermudah ibu hamil dengan Antenatal Care (ANC) mobile dan poli sore hari khusus ANC.

\section{d. Bagi Ibu Hamil dan Keluarga}

Ikut serta mensukseskan program skrining HIV/AIDS di Puskesmas dengan cara meningkatkan kesadaran untuk melakukan pemeriksaan di Puskesmas, keluarga ibu hamil diharapkan partisipasinya dengan mengantar ibu hamil ke Puskesmas agar memberikan kemudahan dan keamanan pada ibu hamil.

\section{e. Peneliti Selanjutnya}

Melakukan penelitian di RSUD untuk menemukan lebih rinci terkait faktor yang mempengaruhi dalam mendukung maupun menghambat pelaksanaan skrining HIV/AIDS bagi ibu hamil.

\section{DAFTAR PUSTAKA}

\section{Buku}

Ali, Zainudin, 2016, Metode Penelitian Hukum, Jakarta: Sinar Grafika.

Azwar, Saifuddin, 2011, Metode Penelitian, Yogyakarta: Pustaka Pelajar.

Darwin, Prinst, 2003, Hukum Anak Indonesia, Bandung: PT. Citra Aditya Bakti.

Depkes RI, 2010, Tes dan Konseling HIV Terintegrasi di sarana Kesehatan/PITC, Jakarta: Direktorat Jenderal Pengendalian Penyakit dan Penyehatan Lingkungan

Depkes RI, 2008, Pedoman Nasional Perawatan, Dukungan dan Pengobatan bagi ODHA, Buku Pedoman untuk Petugas Kesehatan dan Petugas Lainnya, Jakarta: Ditjen PPM dan PL Depkes.

Efendi, Ferry dkk, 2009, Keperawatan Kesehatan Komunitas, Jakarta: Salemba Medika.

Hadjon, Philipus M, 1987, Perlindungan Hukum bagi Rakyat Indonesia, Surabaya: Bina Ilmu.

Hatta, Moh, 2013, Hukum Kesehatan dan Sengketa Medik, Yogyakarta: Liberty Yogyakarta.

Hutapea, Ronald, 2011, AIDS, PMS dan Pemerkosaan, Jakarta: Penerbit Rineka Cipta.

Iqbal, Muh Hasan, 2002, Pokok-pokok Materi Metodologi Penelitian dan Aplikasinya, Bogor: Ghalia Indonesia.

Kementrian Kesehatan RI, 2012, Pedoman Nasional Pencegahan Penularan HIV dari lbu ke Anak (PPIA), Jakarta: Direktorat Jenderal Bina Gizi dan Kesehatan Ibu dan Anak.

Direktorat Jendral Pelayanan Medik.

, 2013, Pedoman Nasional Tes dan Konseling HIV/AIDS, Jakarta: 
SOEPRA Jurnal Hukum Kesehatan

ISSN:2548-818X (media online) Vol. 5 | No. 1 | Juni 2019

Kurnia, Titon Slamet, 2007 , Hak atas Derajat kesehatan Optimal sebagai HAM di Indonesia, Bandung: PT. Alumni.

Laminantang, Leenen H, 1985, Pelayanan Kesehatan dan Hukum, Jakarta: Bina Cipta.

Marwan \& Jimmy, 2009, Kamus Hukum Dictionary of Law Complete Edition, Surabaya: Reality Publisher.

Mertokusuma, Sudikno, 2003, Mengenal Hukum Suatu Pengantar, Cetakan Ke-6, Yogyakarta: Liberty.

Muladi, 2009, Hak Asasi Manusia, Semarang: Refika Aditama.

Nursalam \& Ninuk, 2013, Asuhan Keperawatan Pada Pasien Terinfeksi HIV/AIDS, Jakarta: Salemba Medika.

Notoatmodjo, Soekidjo, 2002, Metode Penelitian Kesehatan, Jakarta: Rineka Cipta.

, 2003, Ilmu Kesehatan Masyarakat ; Prinsip-Prinsip Dasar, Jakarta: Rineka

Cipta.

Noviana, Nana, 2013, Kesehatan Reproduksi HIV-AIDS, Jakarta: Trans Info Media.

Savitri, Niken, 2008, HAM Perempuan-Kritik Teori Hukum Feminis Terhadap KUHP, Bandung: PT Refika Aditama.

Soekanto, Soerjono, 1986, Pengantar Penelitian Hukum, Jakarta: Penerbit Universitas Indonesia

Supardjaja, Komariah Emong, 2007, Laporan AKhir Kompendium tentang Hak Perempuan, Jakarta: Badan Pembinaan Hukum Nasiona Departemen Hukum dan HAM.

Triwibowo, Cecep, 2014, Etika \& Hukum Kesehatan, Yogyakarta: Nuha Medika.

Weinreich, Sonja, 2014, AIDS Sebuah Penyakit Mengubah Dunia, Difaem: German Institute for Medical Mission.

Wiku, Adisasmito, 2007, Sistem Kesehatan, Jakarta: PT Raja Grafindo Persada.

\section{Jurnal}

Gruskin S., Ahmed S., Ferguson L, "Provider innitiated HIV testing and counseling in health facilities - what does this mean for the health and human rights of pregnant women?", Boston: Developing World Bioethics. Diakses di http://www.academia.edu/2728946/PROVIDER_INITIATED_HIV_TESTING_AND_COUNSEL ING_IN_HEALTH_FACILITIES_WHAT_DOES_THIS_MEAN_FOR_THE_HEALTH_AND_HUM AN_RIGHTS_OF_PREGNANT_WOMEN

Novry Oroh, Perlindungan Hak Hidup Terhadap Anak Yang Baru Dilahirkan, 2013, Manado: Program Studi Ilmu Hukum Pascasarjana Universitas Sam Ratulangi Manado Vol../No.5. 
SOEPRA Jurnal Hukum Kesehatan

ISSN:2548-818X (media online) Vol. 5 | No. 1 | Juni 2019

\section{Peraturan Perundang-Undangan}

Undang Undang Dasar 1945, Diakses di http://jdih.pom.go.id/uud1945.pdf

RI, UU No. 39 Tahun 1999 tentang Hak Asasi Manusia (HAM). Diakses di file:///C:/Users/TYAN\%2OFERDIANA\%2OHIKMAH/Downloads/UU_NO_39_1999\%20(2).PDF

RI, UU No. 29 Tahun 2004 tentang Praktik Kedokteran, Diakses di https://luk.staff.ugm.ac.id/atur/UU29-2004PraktikKedokteran.pdf

RI, UU No. 36 Tahun 2009 tentang Kesehatan. Diakses di http://www.depkes.go.id/resources/download/general/UU\%20Nomor\%2036\%20Tahun2\%2 0009\%20tentang\%20Kesehatan.pdf

RI, UU No. 35 Tahun 2014 Tentang Perlindungan Anak. Diakses di http://www.hukumonline.com/pusatdata/downloadfile/lt548fe05d24ad9/parent/lt548fdf d3a87d2

RI, UU No. 36 Tahun 2014 tentang Tenaga Kesehatan. Diakses di http://gajiroum.kemkes.go.id/gajiroum/data/UU_NO_36_2014.pdf

RI, Peraturan Menteri Kesehatan Nomor 290/Menkes/Per/III/2008 tentang Persetujuan Tindakan Kedokteran. http://bksikmikpikkfki.net/file/download/PMK\%20No.\%20290\%20Th\%202008\%20ttg\%20Pers etujuan\%20Tindakan\%2oKedokteran.pdf

RI, Peraturan Menteri Kesehatan Nomor 1464/ Menkes/ Per/X/2010 Tentang Izin Dan Penyelelenggaraan Praktik Bidan. https://sehatsehatiweb.files.wordpress.com/2017/02/pmk-1464-th-2010-ttg-izin-danpenyelenggaraan-praktik-bidan.pdf

RI,Peraturan Menteri Kesehatan Nomor 21 Tahun 2013 tentang Penanggulangan HIV dan AIDS. Diakses di http://www.kebijakanaidsindonesia.net/id/dokumen-kebijakan/send/17peraturan-pusat-national-regulation/361-permenkes-ri-no-21-tahun-2013-tentangpenanggulangan-hiv-dan-aids

RI, Peraturan Menteri Kesehatan Nomor 51 Tahun 2013 tentang Pedoman Pencegahan Penularan HIV dari lbu ke Anak. Diakses di https://webcache.googleusercontent.com/search?q=cache:htojzk4hLoYJ:https://www.m edbox.org/peraturan-menteri-kesehatan-republik-indonesia-nomor-51-tahun-2013tentang-pedoman-pencegahan-penularan-hiv-dari-ibu-keanak/download.pdf $+\& c d=1 \& h l=i d \& c t=c l n k \& g l=i d$

RI, Peraturan Menteri Kesehatan Republik Indonesia Nomor 74 Tahun 2014

Tentang Pedoman Pelaksanaan Konseling dan Tes HIV. Diakses di http://www.Ishk.or.id/uu/PMK\%20No.\%2074\%20ttg\%20Pedoman\%20Pelaksanaan\%20Konsel ing\%20dan\%20Tes\%20HIV.pdf

RI, Peraturan Menteri Kesehatan Nomor 75 Tahun 2014 tentang Pusat Kesehatan Masyarakat. Diakses 
SOEPRA Jurnal Hukum Kesehatan

ISSN:2548-818X (media online) Vol. 5 | No. 1 | Juni 2019

http://www.aidsindonesia.or.id/uploads/20141210110659.PMK_No_75_Th_2014_ttg_Puske smas.pdf

RI, Peraturan Menteri Kesehatan Republik Indonesia Nomor 97 Tahun 2014 Tentang Pelayanan Kesehatan Masa Sebelum Hamil, Masa Hamil, Persalinan, dan Masa Sesudah Melahirkan, Penyelenggaraan Pelayanan Kontrasepsi, Serta Pelayanan Kesehatan Seksual. Diakses di http://kesga.kemkes.go.id/images/pedoman/PMK\%20No.\%2097\%20ttg\%20Pelayanan\%20Ke sehatan\%20Kehamilan.pdf

RI, Peraturan Daerah Provinsi Daerah Istimewa Yogyakarta Nomor 12 Tahun 2010 Tentang Penanggulangan Human Immunodefficiency Virus (HIV) dan Acquired Immuno Defficiency Sindrome (AIDS). Diakses di http://jdih.dprd-diy.go.id/?file=494 